\title{
WPŁYW CECH LITOLOGICZNYCH NA PODATNOŚĆ MAGNETYCZNA LESSÓW Z REJONU WZGÓRZ DALKOWSKICH
}

\author{
KATARZYNA ISSMER \\ Zakład Geomorfologii, Instytut Geoekologii i Geoinformacji \\ Uniwersytet im. Adama Mickiewicza w Poznaniu
}

\begin{abstract}
Magnetic susceptiblity $(M s)$ gives precise information about paleo-environmetal changes. The statistical relation between $M s$ and precise grain-size analysis of loess from Dalków Hills implies that any interpretation of the paleoclimatic record of loess sequences must recognize the detailed grain-size, because such relation could well imply paleo-environmetal changes in sediments without organic residuum. The data presented here suggest that environmental magnetic analysis of loess sediments is mainly dependent on fine silt content described in Aeolian literature as loess fraction.

This study indicates that multiple methods should be employed in analyzing paleoclimatic changes recorded by magnetic susceptibility $(M s)$ in the Polish loess-paleosol sequences. Magnetic susceptibility $(M s)$ correlated with precise paleoclimatic grain-size investigations has yielded numerous records and resources.
\end{abstract}

Keywords: Wzgórza Dalkowskie, loesses, magnetic susceptibility

\section{WPROWADZENIE}

Podatność magnetyczna (magnetic susceptibility - MS) jest wykorzystywana w badaniach dotyczących zmian paleośrodowiskowych. Badaniom podatności magnetycznej poddano osady lessowe z rejonu Wzgórz Dalkowskich w celu poszukiwania relacji pomiędzy cechami litologicznymi (tutaj: uziarnienie i zawartość węglanu wapnia) a wartością podatności magnetycznej. Podatność magnetyczna $\left(\chi_{m}\right)$ to bezwymiarowa wielkość fizyczna charakteryzująca zdolność substancji do zmian jej polaryzacji magnetycznej $(J)$ pod wpływem pola magnetycznego o natężeniu $(H)$. Na wartość podatności magnetycznej istotny wpływ ma skład mineralny, w tym zawartość minerałów magnetycznych, węglanu wapnia i materii organicznej oraz ich uziarnienie. Określana jest poprzez czasowe namagnesowanie skał sztucznym polem magnetycznym o małej amplitudzie. Wpływ na wartość podatności magnetycznej ma przede wszystkim wielkość i ilość minerałów magnetycznych (Thompson, Oldfield 1986). Feng i Johnson (1995) przypisują istotną rolę zawartości węglanu wapnia, a właściwie formie jego występowania, w uzyskiwaniu wartości podatności magnetycznej. $\mathrm{W}$ poziomach paleogleb, jak i w osadach lessowych bogatych w węglan wapnia 
obserwują spadek wartości podatności magnetycznej. Na spadek wartości podatności magnetycznej w poziomach gleb współczesnych bogatych w wapń i frakcje piasku wskazują de Jong i współpracownicy (2000). W poleskich badaniach paleomagnetycznych podatność magnetyczna nazywana jest też magnetyzmem środowiskowym. $O$ istotnym znaczeniu badań podatności magnetycznej w badaniach paleoklimatycznych wielokrotnie w swych pracach mówi Barbara Maher (1988, 1998, 1991).

Celem niniejszej publikacji jest przedstawienie zależności pomiędzy tzw. magnetyzmem środowiskowym reprezentowanym przez podatność magnetyczną $(M s)$ a cechami litologicznymi lessów na przykładzie lessów południowo-zachodniej Polski (tutaj: lessów Wzgórz Dalkowskich).

\section{METODY BADAŃ}

Z rejonu Wzgórz Dalkowskich wyznaczono pięć profili lessowych (Dalków, Cisów, Nielubia, Zabłocie, Wierzchowice), z których pobrano próbki osadów lessowych, określono wartość podatności magnetycznej $(M S)$. Stanowisko Cisów położone jest w obrębie Wzgórz Kożuchowskich (ryc. 1).

Analizy podatności magnetycznej wykonano w Laboratorium Paleomagnetycznym Zakładu Geologii Regionalnej i Geofizyki Państwowego Instytutu Geologicznego w Warszawie. Do pomiaru podatności magnetycznej wykorzystano tzw. mostek, w tym przypadku był to mostek KLY-2 firmy $A G I C O$ z Brna.

Uziarnienie osadów określono metodami optycznymi z zastosowaniem laserowego analizatora uziarnienia Mastersizer Hydro 2000 firmy Malvern, a zawartość węglanu wapnia metodą Scheiblera.

\section{OBSZAR BADAŃ}

Wzgórza Dalkowskie stanowią jednostkę makroregionu Wał Wzgórz Trzebnickich (Kondracki 2000). Obszar badań położony jest w południowo-zachodniej Polsce (ryc. 1, 2), gdzie występują serie lessowe w różnych odmianach litofacjalnych - od lessów masywnych (fot. 1) do laminowanych i smugowanych (Issmer 2001). Są to generalnie młode pokrywy lessowe późnovistuliańskie i holoceńskie. Serie tych lessów zalegają bezpośrednio na osadach fluwioglacjalnych pochodzących z plenivistulianu i często w stropie tych serii fluwioglacjalnych występują graniaki oraz głazy noszące ślady eolizacji, o czym w swych pracach wspominał Schwarzbach (1942). Szczegółowe prace dotyczące zjawisk eolicznych, w tym pokryw lessowych w rejonie Dolnego Śląska, prowadził Czajka. Znalazły one odzwierciedlenie w obszernej monografii dotyczącej tego regionu z 1931 r. - tutaj po raz pierwszy Czajka wskazuje na 


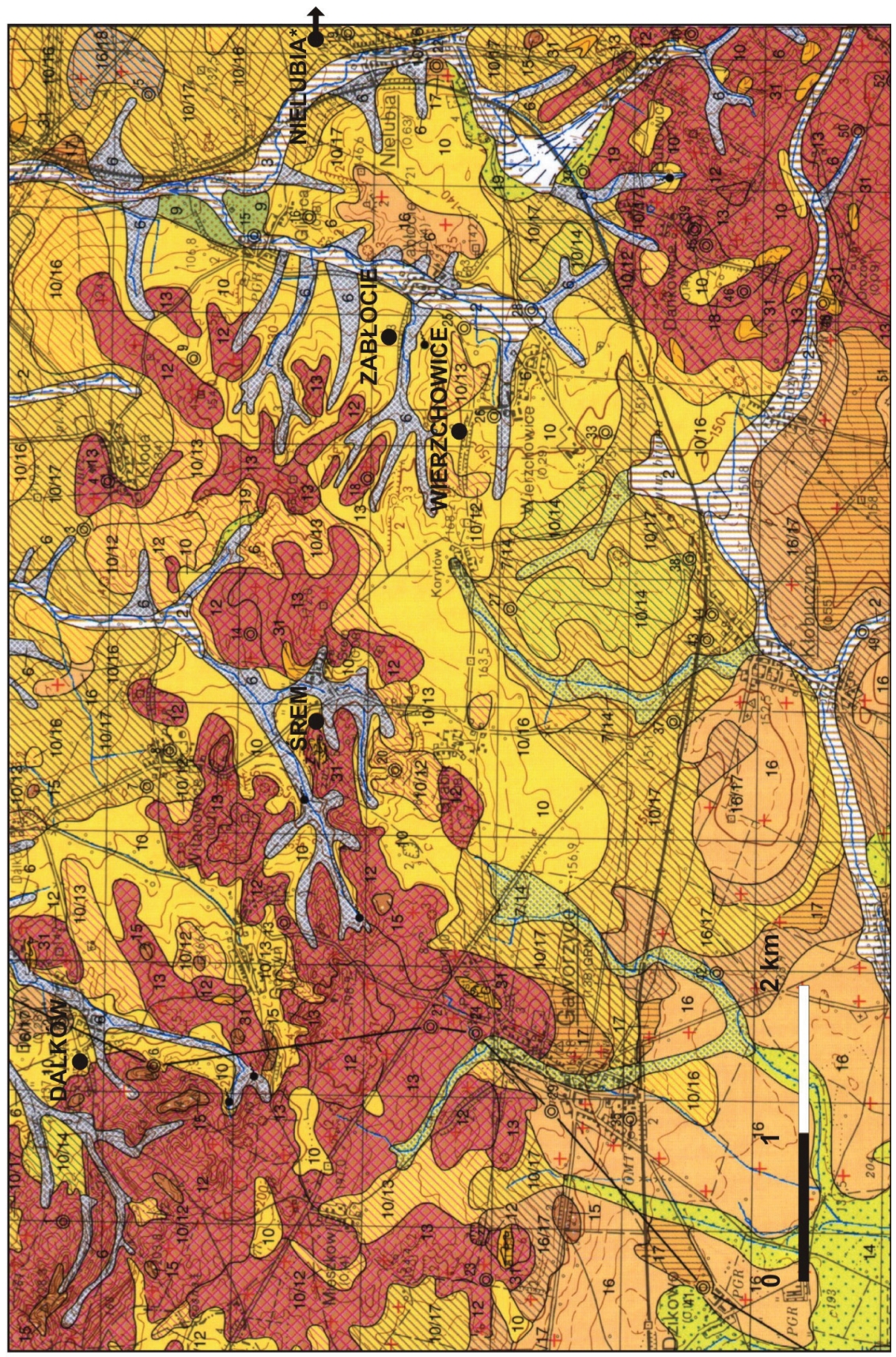






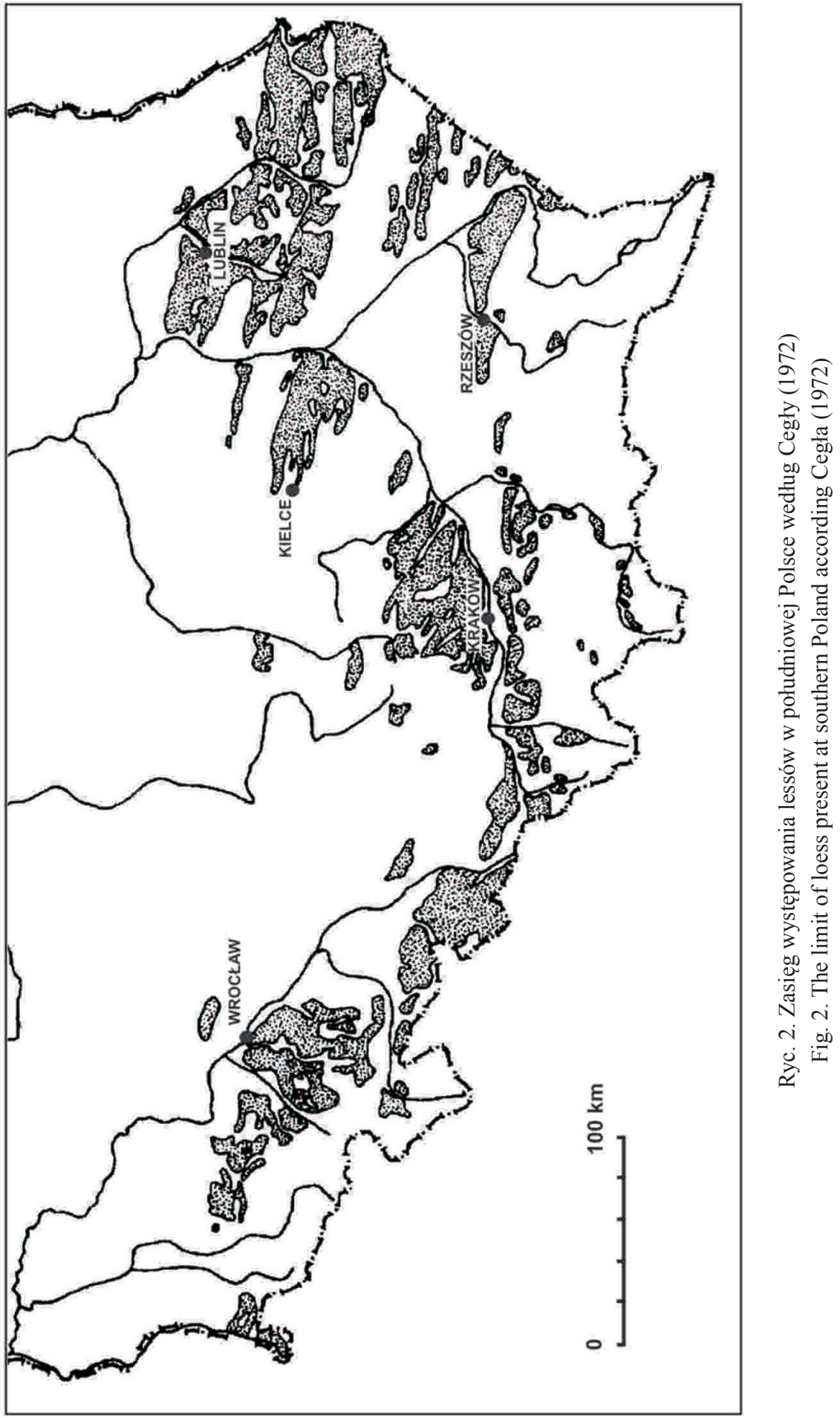




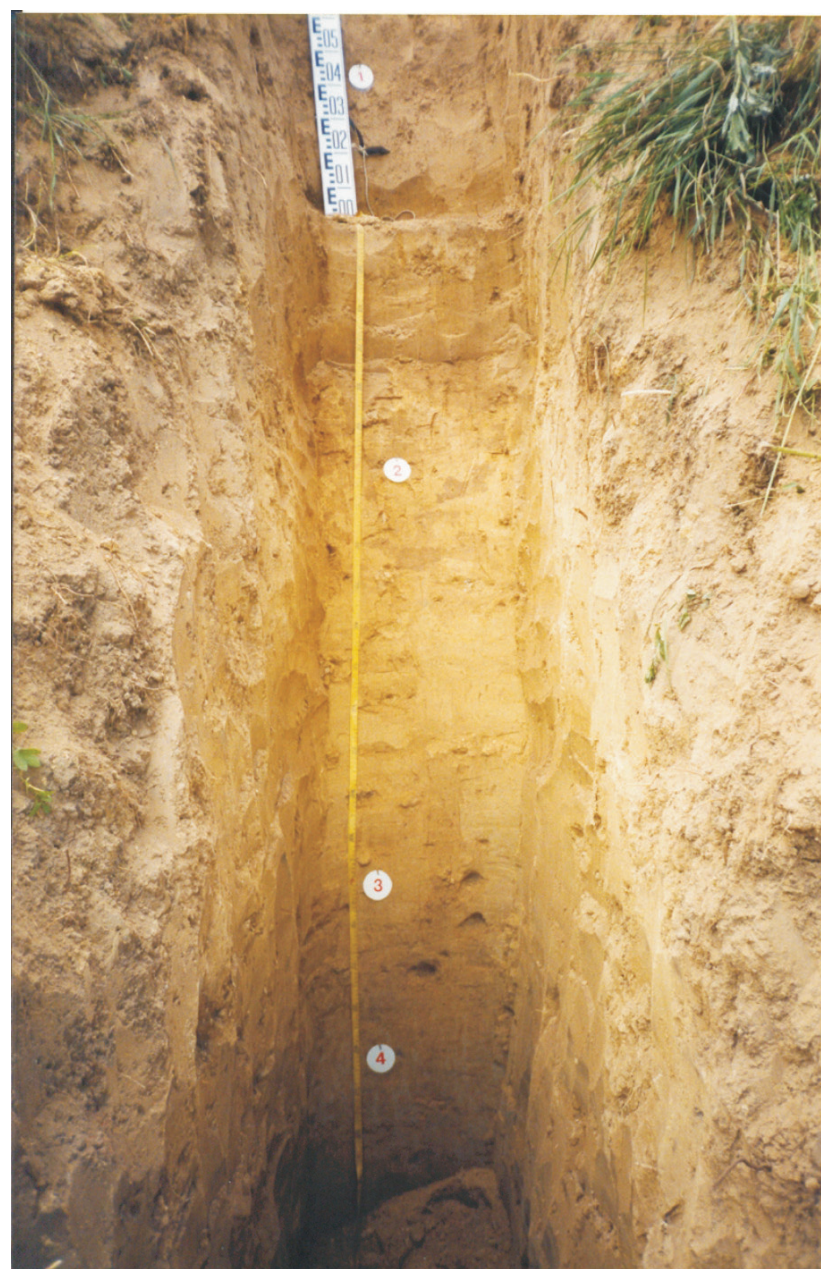

Fot. 1. Profil lessowy w stanowisku Zabłocie, facja lessu masywnego $(1,2,3)$, facja lessu laminowanego (4)

Photo 1. Loess profile at study - site Zabłocie massive lithophacies $(1,2,3)$, laminated lithophacie (4)

związek tych osadów lessowych z rozległą strefą peryglacjalną. W swym najnowszym opracowaniu dotyczącym vistulianu w rejonie Badandeburgii Liedtke (2001) wskazuje na występowanie rozległej strefy peryglacjalnej, co bardzo dobrze koreluje z wynikami badań chronostratygraficznymi dla rejonu Wzgórz Dalkowskich (Issmer 2002).

Serie lessowe w południowo-zachodniej Polsce poddawane są coraz bardziej szczegółowym badaniom paleośrodowiskowym, w tym badaniom paleomagnetycznym (Jary 2007; Issmer 2002). Jednak serie lessowe z rejonu Wzgórz Dalkowskich ze względu na odmienność litofacjalną wymagały osobnego 


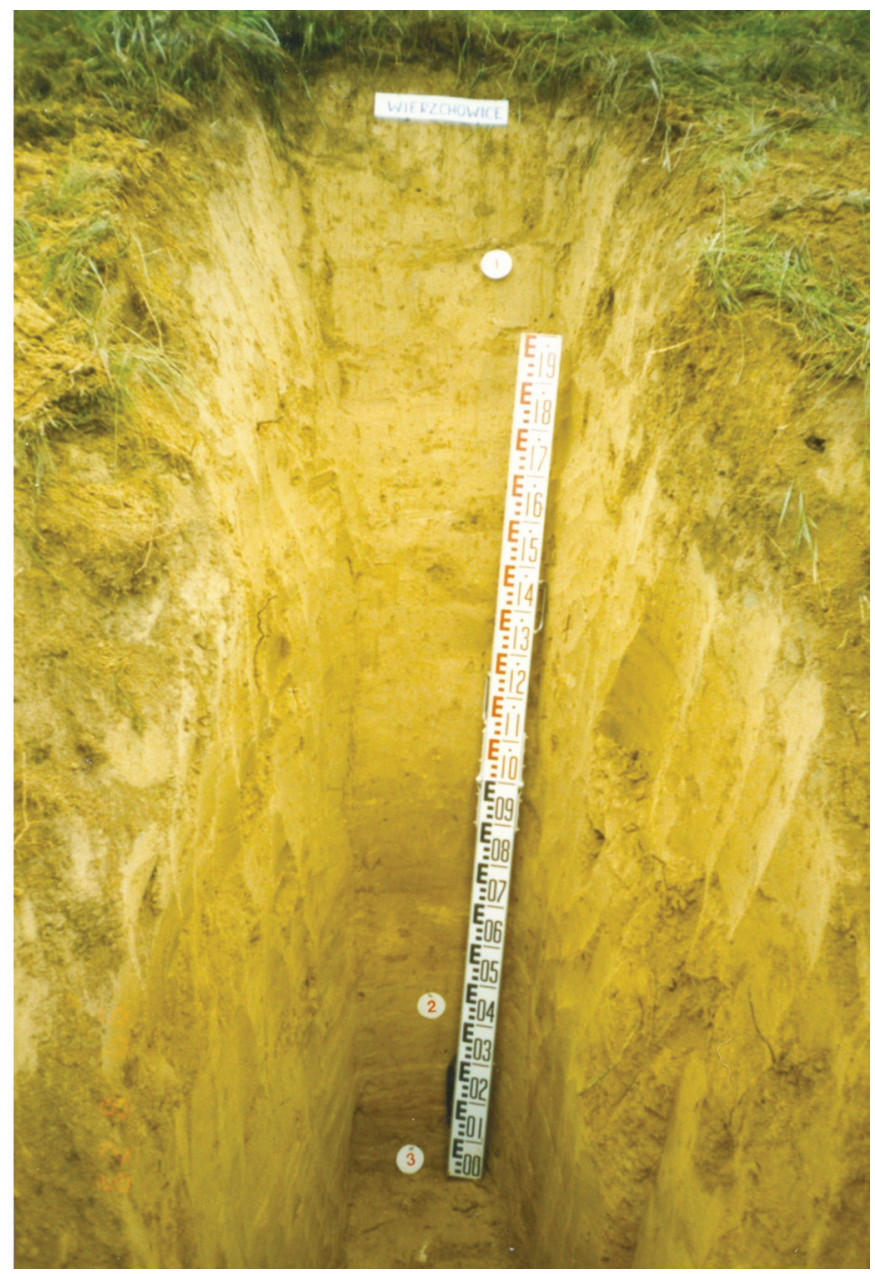

Fot. 2. Profil lessowy w stanowisku Wierzchowice, facja lessu masywnego (1), facja lessu laminowanego (2), osady fluwioglacjalne podłoża (3)

Photo 2. Loess profile at study - site Wierzchowicee massive lithophacies (1), laminated lithophacies (2)

potraktowania, co skłoniło również do sprawdzenia pod względem statystycznym poprawności otrzymywanych wyników wartości podatności magnetycznej.

\section{RELACJE POMIĘDZY CECHAMI LITOLOGICZNYMI A PODATNOŚCIĄ MAGNETYCZNĄ}

W badanych profilach lessowych z rejonu Wzgórz Dalkowskich widoczny jest trend do wzrostu wartości podatności magnetycznej w górę profilu, ku 
warstwom współczesnej gleby. Zmienność podatności magnetycznej $(M S)$ w poszczególnych profilach przedstawiono za pomocą ryciny 3 .

W celu określenia relacji pomiędzy cechami litologicznymi a podatnością magnetyczną obliczono współczynniki korelacji oraz przeprowadzona analizę regresji. Do analiz statystycznych wybrano 74 próbki, które miały określone: podatność magnetyczną $(M S)$, rozkład uziarnienia przy użyciu metod optycznych oraz zawartość węglanu wapnia.

Współczynniki korelacji pomiędzy wartościami podatności magnetycznej a wybranymi wskaźnikami uziarnienia uzyskano dzięki analizie uziarnienia z zastosowaniem metod optycznych (Issmer 2000): Mo - moda, Lso - wskaźnik lessowy, Uni - wskaźnik jednorodności, Io - wskaźnik ilastości oraz procentowa zawartoś węglanu wapnia.

W większości analizowanych stanowisk wyraźna korelacja występuje pomiędzy podatnością magnetyczną $(M S)$ a wskaźnikiem lessowym Lso, a w stanowiskach Cisów i Nielubia jest to zależność odwrotna. Również wartość mody $(\mathrm{Mo})$ pozostaje $\mathrm{w}$ istotnym statystycznie związku z podatnością magnetyczną $(M S)$, również dla danych ze stanowiskach Cisów i Nielubia zależność jest dodatnia. W przypadku wskaźnika ilastości (Io) tylko dla stanowiska Nielubia i Zabłocie zachodzi istotny statystycznie związek, chociaż zależność ta pozostaje w odmiennych relacjach. Wskaźnik jednorodności tylko dla osadów lessowych ze stanowiska Zabłocie wykazuje istotny statystycznie związek z wartością podatności magnetycznej (tab. 1).

Określono również zależność statystyczną, wyrażoną współczynnikiem korelacji, pomiędzy podatnością magnetyczną $(M S)$ a uziarnieniem, przedstawionym w postaci procentowego udziału w poszczególnych frakcjach [\% obj.]. Dla badanych osadów w wydzielanych stanowiskach zależność ta jest znacząca dla frakcji piasku, pyłu drobnego i frakcji iłu koloidalnego (tab. 2).

Do podobnych wniosków doszli de Jong i współpracownicy (2000), badając relacje pomiędzy wartością podatności magnetycznej a uziarnieniem poszczególnych poziomów glebowych, dla gleb typu czarnoziem i gleb glejowych w Saskatchewan (Kanada). Wspomniani autorzy uzyskali dodatnią korelację pomiędzy wartością podatności magnetycznej a zawartością piasku (>53 $\mu \mathrm{m})$ w badanych glebach.

W analizowanych profilach lessów z rejonu Wzgórz Dalkowskich ze wzrostem zawartości węglanu spada wartość podatności. W większości badanych profili zachodzi wysoka ujemna korelacja pomiędzy wartością podatności magnetycznej a zawartością węglanu wapnia w osadach (tab. 2). Korelacja ta uzyskuje najwyższe wartości w profilach lessowych, w których występują nagromadzenia wtórnego węglanu wapnia w postaci konkrecji węglanowych tzw. kukiełek lessowych.

Na podstawie przeprowadzonych analiz można wskazać, że odpowiednią miarą relacji pomiędzy uziarnieniem a podatnością magnetyczną jest zarówno 

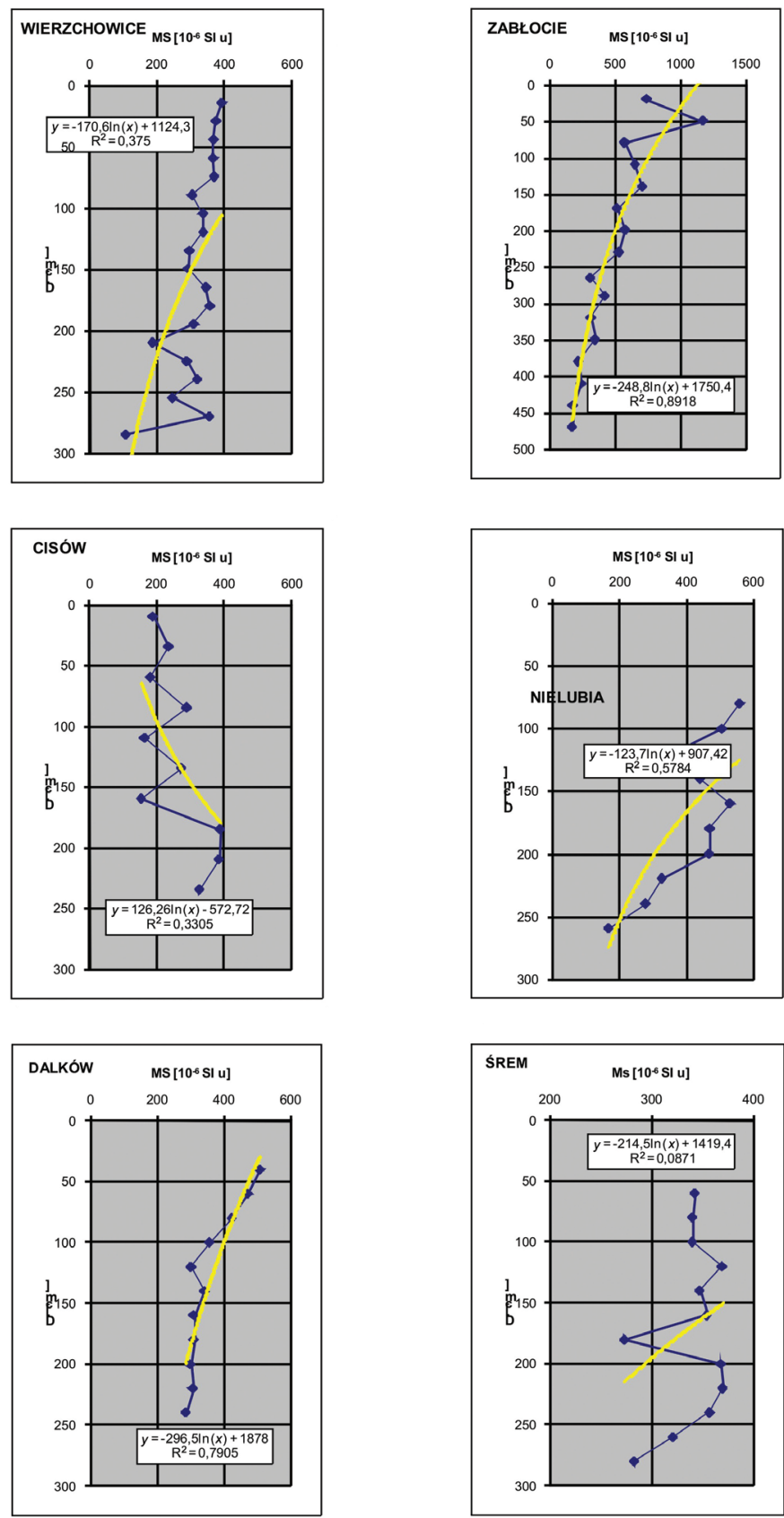

Ryc. 3. Zmienność podatności magnetycznej $(M s)$ w badanych profilach lessowych z rejonu Wzgórz Dalkowskich, dodatkowo zaznaczono statystycznie określoną linię trendu zmian magnetyzmu środowiskowego

Fig. 3. Variability of magnetic susceptibility $(M s)$ In investiged loess profiles from Dalków Hills Additionally marked statistical desribed trend's line of environmental magnetism changes 
Tabela 1. Wartości statystyczne podatności magnetycznej: Avg - średnia, Std-odchylenie standardowe, Max - wartość maksymalna, Min. - wartość minimalna, oraz współczynniki korelacji między podatnością magnetyczną $(M S)$ a cechami uziarnienia określonymi przez następujące wskaźniki uziarnienia: Mo - moda, Lso - wskaźnik lessowy, Uni - wskaźnik jednorodności, Io - wskaźnik ilastości; wskaźniki uziarnienia określono na podstawie danych otrzymanych z zastosowaniem metod optycznych

Table 1. Statistical values of magnetic susceptiblity $(M s): A v g$ - avaradge, Std - statistical deviation standardowe, Max - maxima value, Min - minimal value, and correlation coefficient

between magnetic susceptibilty and grain-size featuresdecribed by Mo - moda, Lso - less coeficient, Uni - uniformity coefficient, Io - clay cofficient; All grain-size coefficients described by data received from optical grain-size analysis

\begin{tabular}{|c|c|c|c|c|c|c|}
\hline \multirow[t]{2}{*}{ Stanowisko } & \multirow{2}{*}{\multicolumn{2}{|c|}{$\begin{array}{c}\text { Wartości statystyczne } \\
\text { podatności magnetycznej } \\
M S\left[10^{-6} \mathrm{SI} \mathrm{u}\right]\end{array}$}} & \multicolumn{4}{|c|}{$\begin{array}{l}\text { Współczynnik korelacji pomiędzy } \\
\text { podatnością magnetyczną (MS) } \\
\text { a wskaźnikami uziarnienia: }\end{array}$} \\
\hline & & & Mo & Lso & Uni & 10 \\
\hline Wierzchowice & $\begin{array}{l}\text { Avg } \\
\text { Std } \\
\text { Max } \\
\text { Min. }\end{array}$ & $\begin{array}{l}312,89 \\
69,90 \\
391 \\
108\end{array}$ & $-0,23$ & 0,33 & $-0,11$ & $-0,22$ \\
\hline Zabłocie & $\begin{array}{l}\text { Avg } \\
\text { Std } \\
\text { Max } \\
\text { Min. }\end{array}$ & $\begin{array}{c}485,19 \\
261,68 \\
1174 \\
179\end{array}$ & $-0,81$ & 0,85 & 0,75 & 0,74 \\
\hline Cisów & $\begin{array}{l}\text { Avg } \\
\text { Std } \\
\text { Max } \\
\text { Min. }\end{array}$ & $\begin{array}{c}259,60 \\
88,26 \\
390 \\
155\end{array}$ & 0,53 & $-0,64$ & 0,39 & $-0,27$ \\
\hline Nielubia & $\begin{array}{l}\text { Avg } \\
\text { Std } \\
\text { Max } \\
\text { Min. }\end{array}$ & $\begin{array}{l}410,20 \\
124,73 \\
559 \\
167\end{array}$ & 0,31 & $-0,33$ & $-0,21$ & $-0,81$ \\
\hline Śrem & $\begin{array}{l}\text { Avg } \\
\text { Std } \\
\text { Max } \\
\text { Min. }\end{array}$ & $\begin{array}{l}339,67 \\
31,82 \\
371 \\
274\end{array}$ & $-0,39$ & 0,48 & $-0,27$ & 0,17 \\
\hline Dalków & $\begin{array}{l}\text { Avg } \\
\text { Std } \\
\text { Max } \\
\text { Min. }\end{array}$ & $\begin{array}{l}358,09 \\
76,86 \\
510 \\
288\end{array}$ & $-0,64$ & 0,65 & 0,20 & 0,44 \\
\hline Łącznie & $\begin{array}{l}\text { Avg } \\
\text { Std } \\
\text { Max } \\
\text { Min. }\end{array}$ & $\begin{array}{c}364,37 \\
153,65 \\
1174 \\
108\end{array}$ & $-0,48$ & 0,59 & $-0,06$ & $-0,28$ \\
\hline
\end{tabular}


Tabela 2. Współczynniki korelacji między podatnością magnetyczną $(M S)$ a udziałem procentowym w głównych frakcjach uziarnienia; dane otrzymano przy użyciu metod optycznych oraz zawartości węglanu wapnia

Table 2. Correlation coefficients between magnetic susceptibility $(M s)$ and percentage value in main grain fractions (sand, coarse silt, fine silt, clay, coloidal clay) described by means of the optical grain-size analysis and the content of calcium carbonate $-\mathrm{CaCo}_{3}$

\begin{tabular}{lcccccc}
\hline \multirow{2}{*}{ Stanowisko } & $\begin{array}{c}\text { Piasek } \\
>100 \mathrm{~mm}\end{array}$ & $\begin{array}{c}\text { Pył gruby } \\
50-100 \\
\mathrm{~mm}\end{array}$ & $\begin{array}{c}\text { Pył } \\
\text { drobny } \\
20-50 \mathrm{~mm}\end{array}$ & $\begin{array}{c}\text { \# } \\
<20 \mathrm{~mm}\end{array}$ & $\begin{array}{c}\text { It } \\
\text { koloidalny } \\
<2 \mathrm{~mm}\end{array}$ & $\begin{array}{c}\mathrm{CaCO}_{3} \\
{[\%]}\end{array}$ \\
\cline { 2 - 7 } Wierzchowice & $-0,29$ & $-0,14$ & 0,39 & 0,04 & $-0,22$ & $-0,62$ \\
Zabłocie & $-0,78$ & $-0,88$ & 0,83 & 0,77 & $-0,74$ & $-0,68$ \\
Śrem & $-0,37$ & $-0,03$ & 0,47 & 0,22 & 0,18 & 0,55 \\
Nielubia & 0,29 & 0,27 & $-0,01$ & $-0,41$ & $-0,81$ & $-0,25$ \\
Dalków & $-0,59$ & 0,02 & 0,73 & 0,19 & 0,44 & $-0,91$ \\
Cisów & 0,57 & $-0,47$ & $-0,59$ & $-0,29$ & $-0,23$ & $-0,21$ \\
\hline Łącznie & $-0,40$ & $-0,29$ & 0,63 & 0,10 & $-0,30$ & $-0,27$ \\
\hline
\end{tabular}

moda $(M o)$, jak i wskaźnik lessowy ( $L s o$ ), a spośród frakcji istotne statystycznie są dwie - frakcja piasku i pyłu drobnego. Dlatego przeprowadzono analizę regresji pomiędzy: podatnością magnetyczną $(M S)$ a modą $(M o)$, wskaźnikiem lessowym (Lso), procentową zawartością piasku i pyłu drobnego oraz węglanu wapnia.

Precyzyjny pomiar uziarnienia $\mathrm{w}$ relacji z podatnością magnetyczną może istotnie wpłynąc na interpretację otrzymywanych danych paleomagnetycznych. Badania takie są intensywnie prowadzone dla lessów chińskich (Beer i in. 1993; An $i$ in. 1991a, b; Zhou i in. 1990; Kukla i in. 1988; Vandenberghe i in. 1997) $i$ amerykańskich (Beget i in. 1990; Feng i in. 1994a, b). W zamierzeniach dotyczących relacji pomiędzy podatnością magnetyczną a rozwojem tzw. kultur magnetycznych bakterii (magnetotactic bacteria (MTB)), w przypadku osadów lessowych i towarzyszącej jej ciągłej pedogenezy, wydają się być, niezwykle istotne.

\section{LITERATURA}

An Z., Kukla G.J., Porter S.C., Xiao J., 1991a: Late Quaternary dust flow on the Chinese Loess Plateau. Catena, 18, 125-132.

An Z., Kukla G.J., Porter S.C., Xiao J., 1991b: Magnetic susceptibilty evidence of monsoon variation on the Loess Plateau of central China during the last 130,000 years. Quat. Res., 36, 29-36.

Beer J., Shen C.-D., Heller F., Liu T.-S., Bonani G., Dittrich B., Suter M., Kubik P.W., 1993: Be-10 and magnetic susceptibility in Chinese loess. Earth Planet. Sci. Lett., 20, 57-60.

Beget J.E., Stone D.B., Hawkins D.B., 1990: Paleoclimatic forcing of magnetic susceptibility variations in Alaskan loess during the late Quaternary. Geology, 18, 40-43. 
Cegła J., 1972: Sedymentacja lessów Polski [Loess sedimentation in Poland]. Acta Univ. Wratislaviensis, 168, $72 \mathrm{~s}$.

Czajka W., 1931: Der Schlesische Landrücken. Veröff. Schles. Ges. Erdk., 11, 156.

Dearing J.A., Livingstone A., Zhou L.P., 1996b: A late Quaternary magnetic record of Tunisian loess and its palaeoclimatic significance. Geophys. Res. Lett., 23, 189-192.

de Jong E., Pennock D.J., Nestor P.A., 2000: Magnetic susceptibilty of soils in different slope positions in Saskatchewan, Canada, Catena, 40, 291-305.

Derbyshire E., Kemp R., Meng X., 1995: Variations in less and palaeosol properties as indicators of palaeoclimatic gradients across the Loess Plateau, North China. Quat. Sci. Rev., 14, 681-697.

Feng Z.-D., Johnson W.C., 1995: Factors affecting the magnetic susceptibility of a loess-soil sequence, Barton County, Kansas, USA. Catena, 24, 25-37.

Feng Z.-D., Johnson W.C., Lu Y.-C., Sprowl D.R., 1994a: Temporal variations in loess depositional environment in central Kansas during the past 400,000 years. Earth Surf. Process. Landforms, 19, 2, 55-68.

Feng Z.-D., Johnson W.C., Lu Y.-C., Ward P.A., 1994b: Climatic signals from loess-soil sequences in the central Grat Plains, U.S.A. Palaeogeor. Paleoecol. Palaeoclimatol., 110, 3-4, 345-358.

Issmer K., 2000: Późnoplejstoceńskie osady lessowe na seriach glacjalnych pótnocno-zachodniej Polski oraz ich paleogeograficzne znaczenie. PTPN, 27, 1-151.

Issmer K., 2001: Vistulian loess deposits in western Poland and their paleoenvironmental implications. Quaternary Internat., 76/77, 129-139.

Jary Z., 2007: Zapis zmian klimatu w górnoplejstoceńskich sekwencjach lessowo-glebowych w Polsce $i$ w zachodniej części Ukrainy. Rozprawy Naukowe Instytutu Geografii i Rozwoju Regionalnego Uniw. Wrocławskiego, 1, 134 s.

Kondracki J., 2000: Geografia fizyczna Polski. Wyd. Nauk. PWN, Warszawa, 441 s.

Kukla G., Heller F., Liu X.M., Xu T.-C., Liu T.-S., An Z.-S., 1988: Pleistocene climates in China dated by magnetic susceptibilty. Geology, 16, 811-814.

Lidtke H., 2001: Das nordöstliche Brandenburd während der Weichseleiszeit. [W:] S. Bussemer (red.), Das Erbe der Eiszeit, 119-134.

Maher B.A., 1986: Characterization of soils by mineral magnetic measurements. Phys. Earth Planet. Inter, 42, 76-92.

Maher B.A., 1988: Magnetic properties of some synthetic submicronmagnetites. Geophys. J., 94, 83-96.

Maher B.A., 1991: Inorganic formation of ultrafine-grained magnetite. [W:] R.B. Frankel, R.P. Blakemore (red.), Iron Biominerals. Plenum, New York, 179-191.

Maher B.A., Thompson R., 1992: Paleoclimatic significance of the mineral magnetic record of the Chinese loess and paleosols. Quat. Res., 37, 155-170.

Maher B.A., Thompson R., 1995: Paleorainfull reconstructions from pedogenic magnetic susceptibility variations the Chinese loess and paleosols. Quat. Res., 44, 383-391.

Maher B.A., Thompson R., Zhou L.P., 1994: Spatial and temporal reconstructions of changes in the Asian palaeomonsoon: A new mineral magnetic approach. Earth Planet. Sci. Left., 125, 461-471.

Nawrocki J., Bogucki A., Maruszczak H., Wojcik A., 1995: The magnetic susceptibility record in the Polish and western Ukranian loess paleosol sequences conditioned by paleoclimate. Terra Nostra, 2, 197.

Nawrocki J., Polechińska O., Boguckij A., Łanczont M., 2006: Palaeowind directions recorded in the youngest loess of Poland and western Ukraine as derived from anisotropy of magnetic susceptibilitymeasurements. Boreas, Vol. 35, 266-271.

Schwarzbach M., 1942: Das Diluvium Schlesiens. Neuen Jb. Miner. Geol. Palänt., Bd. 86, $189-215$.

Thompson R., Oldfield R., 1986: Environmetal Magnetism. London. 
Vandenberghe J., An Z.S., Nugteren G., Lu H., Van Huissteden J., 1997: New absolute time scale for the Quaternary climate in the Chinese loess region by grain-size analysis. Geology, 25, $1,35-38$.

Walden J., Wadsworth E., Austin W.E.N., Peters C., Scourse J.D., Hall I.R., 2006: Compositional variability of ice-rafted debris in Heinrich layers 1 and 2 on the northwest European continental slope identified by environmental magnetic analyses. J. Quaternary Sci., Vol. 22.

Zhou L.-P., Oldfield F., Wintle A.G., Robimson S.G., Wang J.-T., 1990: Partly pedogenic origin of magnetic variations in Chinese loess. Nature, 346, 737-739. 